\title{
TANGGUNGJAWAB PARA PIHAK DALAM PERJANJIAN JUAL BELI KENDARAAN BERMOTOR BEKAS PAKAI DIHUBUNGKAN DENGAN PERAN PEMERINTAH DAERAH UNTUK MENINGKATKAN PENDAPATAN ASLI DAERAH YANG BERKEPASTIAN HUKUM
}

\author{
Fadhlullah \\ Dosen Universitas Muhammadiyah Aceh \\ e-mail: fadhlullahhasan@yahoo.co.id
}

\begin{abstract}
Abstrak-Perjanjian jual beli kendaraan bermotor bekas pakai termasuk dalam perjanjian formal, artinya undang-undang telah menentukan bagi para pihak yang terlibat dalam perjanjian jual beli harus mengikuti semua ketentuan yang telah ditentukan. Ketentuan tersebut harus dilaksanakan secara menyeluruh, sehingga tidak merugikan para pihak atau pihak ketiga. Pasal 1320 ayat (4) jo. Pasal 1337 KUHPerdata menerangkan bahwa para pihak tidak bebas untuk membuat perjanjian yang menyangkut causa yang dilarang oleh undang-undang. Akibat hukum perjanjian yang beris isebab yang tidak halal, perjanjian tersebut batal demi hukum. Dalam pelaksanaan jual beli kendaraan bermotor, para pihak (penjual dan pembeli) tidak mengindahkan ketentuan tersebut. Tujuan penelitian adalah untuk mengetahui tanggungjawab para pihak dalam perjanjianjual beli kendaraan bermotor bekas pakai yang tidak balik nama dihubungkan dengan kepastian hukum. Disamping itu, untuk mengetahui peranan pemda dalam meningkatkan Pendapatan Asli Aceh yang bersumber dari bea balik nama kendaraan bermotor. Hasil penelitian membuktikan bahwa pembeli dalam perjanjian jual beli tidak betanggungjawab secara personal dan telah melakukan perbuatan melawan hukum. Dengan cara tidak tidak melakukan balik nama kendaraan bermotor, sehingga merugikan diri sendiri dan pihak lain karena tidak melakukan balik nama kendaraan bermotor. Akibat perbuatan tersebut tidak terselenggaranya peningkatan Pendapatan Asli Aceh serta target pencapaiannya. Penyebabnya adalah kesadaran hukum wajib pajak masih relatif rendah dan tingginya BBNKB. Pemda sesuai undang-undang berperan aktif dalam meningkatkan Pendapatan Asli Aceh yang bersumber dari BBNKB melalui fungsi anggaran dan fungsi mengatur.
\end{abstract}

\section{Kata Kunci: Jual Beli, BBNKB, BNKB, Pemegang.}

Abstract-The sale and purchase agreement of secondhand motor vehicle is included in the formal agreement, meaning that the law has determined that the parties involved in the sale and purchase agreement must follow all the stipulations those have been determined. Such provisions should be implemented thoroughly, so it will not harm parties or third parties. Article 1320 paragraph (4) jo. Article 1337 of the Civil Code states that the parties are not free to enter into agreements concerning the causa prohibited by law. As a result of the law of the agreement which contains the unlawful causes, the agreement became null and void. In the execution of the motor vehicles trading, the parties (sellers and buyers) disregard the provisions. The purpose of this research is to know the responsibility of the parties in the secondhand motor vehicle purchase agreement that is not transfering the ownership of that vehicle, associated with legal certainty. In addition, to know the role of local government in increasing Acehnese Original Income derived from transfering the motor vehicle ownership to the new (current) owner. Research proves that the buyer in the sale and purchase agreement is not personally responsible and has committed act against the law. With ignoring the ownership transfer, it will harm themselves and others for not doing that. As a result of these actions, the Increase in Acehnese Original Income and its achievement targets 
become unrealized. The cause is the legal awareness of taxpayers is still relatively low, while the BBNKB is high. Local government, as according to constitution, take an active role in increasing Acehnese Original Income derived from BBNKB through the function of budget and regulating functions.

Keywords: Purchase, BBNKB, BNKB, Holder.

\section{A. PENDAHULUAN}

Pemerintah telah memberikan hasil-hasil pembangunan melalui kegiatan pemerintahan meliputi segala bidang, sehingga setiap daerah menjadi maju dan berkembang. Peningkatan taraf hidup dan kesejahteraan yang adil dan merata yang ingin diusahakan melalui pembangunan itu, hanya dapat tercapai jika ada partisipasi aktif masyarakat agar melaksanakan kewajibannya terhadap negara. Salah satu kewajiban sebagaimana yang dinginkan di atas adalah membayar pajak.

Pajak merupakan sumber penerimaan pendapatan asli daerah perlu terus. ditingkatkan. Salah satu yang berasal dari pajak adalah Bea Balik Nama Kendaraan Bermotor (BBNKB). Bea Balik Nama Kendaraan Bermotor dipungut dari balik nama kendaraan bermotor antara penjual dan pembeli setelah terjadi perjanjian jual beli kendaraan bermotor. Pada masa sekarang sesuai dengan perkembangan tehnologi, pola kehidupan dan penghidupan masyarakat dewasa ini, para pemilik kendaraan bermotor tidak dapat lagi dianggap sebagai golongan yang berkemampuan lebih.

Oleh karenanya, pemilikan kendaraan bermotor tersebut telah merupakan salah satu sarana usaha. Pemilikannya ada yang berdasarkan warisan, hibah maupun jual beli. Perjanjian jual beli merupakan suatu persetujuan yang paling lazim diadakan oleh para anggota masyarakat.

\section{B. HASIL DAN PEMBAHASAN}

\section{Perjanjian Jual Beli}

Perjanjian jual beli secara historis merupakan species dari genus perjanjian tukar menukar. Karena pada mulanya terjadi tukar-menukar barang para pihak. Pihak penjual wajib menyerah barang dan pihak pembeli wajib menyerahkan barang lain, yaitu alat pembayaran yang sah adalah uang. 
Terkait dengan perjanjian jual beli, (R. Subekti, 2003:79), menjelaskan yang dijanjikan oleh pihak yang satu (pihak penjual), menyerahkan atau memindahkan hak miliknya atas barang yang ditawarkan, sedangkan yang dijanjikan oleh pihak lain (pembeli), membayar harga yang telah disetujuinya. Meskipun tidak disebutkan dalam naskah satu undang-undang, namun telah semestinya bahwa "harga" ini harus berupa sejumlah uang. Karena apabila tidak demikian, dan harga itu berupa barang, maka bukan lagi jual beli yang terjadi tetapi tukar menukar atau barter.

\section{Pasal 1457 KUH Perdata} (Ratna Artha Windari, 2014:26) menentukan: "Jual beli adalah salah satu persetujuan yang mengikat, dengan mana pihak yang satu mengikatkan dirinya untuk menyerahkan suatu barang, dan pihak yang lain untuk membayar harga yang dijanjikan".

Sesuai dengan ketentuan (M. Yahya Harahap, 1986:181) yang terdapat dalam Pasal 1457 KUHPerdata, persetujuan jual beli sekaligus mempertanggungjawabkan dua kewajiban kepada para pihak, yaitu:

a. Kewajiban pihak penjual menyerahkan barang yang dijual kepada pembeli;

b. Kewajiban pihak pembeli membayar harga barang yang dibeli kepada penjual.

Perjanjian jual beli dianggap sudah berlangsung antar pihak penjual dengan pihak pembeli, apabila mereka telah menyetujui dan bersepakat "keadaan benda" dan "harga" barang. Sekalipun barangnya belum diserahkan dan harganya belum dibayar (Pasal 1458 KUHPerdata). Jual beli tiada lain daripada "Persesuaian Kehendak" (wils overeen stemming) antara penjual dan pembeli mengenai "barang" dan "harga". Barang dan hargalah yang menjadi essensialia perjanjian jual beli. Tanpa ada barang yang hendak di jual, tidak mungkin terjadi jual beli. Sebaliknya jika barang objek jual beli tidak dibayar dengan sesuatu harga jual beli dianggap tidak ada. Cara dan terbentuknya jual beli, bisa terjadi secara "terbuka/openbaar" seperti yang terjadi pada penjualan atas dasar 
“eksekutorial" atau yang disebut executorile verkoop. Penjualan eksekutorial harus dilakukan melalui "lelang" di muka umum oleh pejabat kantor lelang.

Cara dan bentuk penjualan eksekutorial yang bersifat umum ini, jarang sekali terjadi. Penjualan demikian harus memerlukan keputusan pengadilan. Karena itu jual beli yang terjadi dalam lalu lintas kehidupan sehari-hari adalah jual beli antara tangan ke tangan. Yakni jual beli antar penjual dan pembeli tanpa campur tangan pihak pejabat lelang dan tidak perlu di muka umum. Bentuk jual belinyapun, terutama jika objek barang-barang bergerak, cukup dilakukan dengan lisan. Kecuali mengenai barang-barang tertentu (barang bergerak terdaftar), dan mengenai objeknya barang-barang tidak bergerak pada umumnya memerlukan akte jual beli. Tujuan akte itu hanya sekedar mensejajari jual beli itu dengan keperluan penyerahan juridis (juridisch levering) di samping penyerahan nyata (feitelijke leavering) (Rahmadi Usman, 2011:208).

\section{Peralihan Hak Milik}

Pasal 1459 KUHPerdata menentukan, bahwa hak milik tidak dengan sendirinya menurut hukum berpindah kepada pembeli. Melainkan hak milik itu baru berpindah sesudah barang yang dibeli diserahkan sesuai dengan aturan yang ditetapkan. Dengan demikian, maksud pasal tersebut, agar barang objek jual beli menjadi sah milik pembeli, haruslah penyerahan barang itu sesuai dengan aturan yang berlaku terhadap objek jual beli tersebut.

Perjanjian jual jual beli mengenal asas kebebasan berkontrak yang ditafsirkan dari Pasal 1338 ayat (1) KUHPerdata. Menurut Hukum Perdata yang berlaku di Indonesia, kebebasan berkontrak dapat disimpulkan dari ketentuan Pasal 1338 ayat (1) KUHPerdata, yang menyatakan bahwa semua kontrak (perjanjian) yang dibuat secara sah berlaku sebagai undang-undang bagi mereka yang membuatnya. Sumber dari kebebasan berkontrak adalah kebebasan individu sehingga yang merupakan titik tolaknya adalah kepentingan individu pula. Dengan demikian dapat dipahami bahwa 
kebebasan individu memberikan itikad baik. Oleh karena itu para kepadanya kebebasan untuk pihak tidak dapat menentukan berkontrak.

Apakah asas kebebasan berkontrak dapat diartikan sebagai bebas mutlak? apabila kita mempelajari KUHPerdata, ternyata asas kebebasan berkontrak itu bukannya bebas mutlak. Ada beberapa pembatasan yang diberikan oleh pasal-pasal KUHPerdata terhadap asas ini yang membuat asas ini merupakan asas tidak tak terbatas. Pasal 1320 ayat (4) jo. 1337 KUHPerdata menentukan bahwa para pihak tidak bebas untuk membuat perjanjian yang menyangkut causa yang dilarang oleh undang-undang.

Menurut undang-undang causa atau sebab itu halal apabila tidak dilarang oleh undang-undang dan tidak bertentangan dengan ketertiban umum dan kesusilaan. Akibat hukum perjanjian yang berisi sebab yang tidak halal ialah bahwa perjanjian itu batal demi hukum.

Kemudian pembatasan terhadap asas kebebasan berkontrak juga dapat disimpulkan melalui Pasal 1338 ayat (3) yang menyatakan bahwa suatu perjanjian hanya dilaksanakan dengan sekehendak hatinya klausul-klausul yang terdapat dalam perjanjiian tetapi harus didasarkan dan dilaksanakan dengan itikad baik. Perjanjian yang didasarkan pada itikad buruk misalnya penipuan mempunyai akibat hukum perjanjian tersebut dapat dibatalkan. Pembahasan dalam tulisan ini yang menjadi objek jual beli adalah kendaraan bermotor bekas pakai roda empat. Transaksi jual beli merujuk pada ketentuan-ketentuan yang terdapat dalam KUHPerdata dan beberapa peraturan perundangan lainnya yang akan disebutkan berikutnya. Pada ketentuan-ketentuan tersebut, mengatur tentang tanggungjawab para pihak dalam transaksi jual beli kendaraan bermotor, tata cara penyerahannya selain untuk mencapai kepastian hukum juga dalam rangka meningkatkan pendapatan asli daerah. Melalui Undang-undang Nomor 28 Tahun 2009 tentang Pajak Daerah dan Retribusi Daerah, pemerintah pusat mengalihkan beberapa jenis pajak yang semula ditarik oleh pemerintah pusat menjadi pajak 
daerah. Selain itu, terdapat perluasan basis pajak yang sudah ada, yaitu untuk Pajak Kendaraan Bermotor (PKB) dan Bea Balik Nama Kendaraan Bermotor (BBNKB) diperluas hingga mencakup kendaraan pemerintah.

Menurut ketentuan Pasal 1 ayat

(14) Undang-undang Nomor 28 Tahun 2009 tentang Pajak Daerah dan Retribusi Daerah dijelaskan:

"Bea Balik Nama Kendaraan Bermotor adalah pajak atas penyerahan hak milik kendaraan bermotor sebagai akibat perjanjian dua pihak atau perbuatan sepihak atau keadaan yang terjadi karena jual beli, tukar menukar, hibah/hibbah, warisan, atau pemasukan ke dalam badan usaha".

Perjanjian jual beli termasuk dalam kelompok perjanjian bernama, artinya undang-undang telah memberikan nama tersendiri dan memberikan pengaturan secara khusus terhadap perjanjian ini. Perjanjian jual beli saja tidak lantas menyebabkan beralihnya hak milik atas barang dari tangan penjual ke tangan pembeli sebelum dilakukan penyerahan (levering). Pada hakekatnya perjanjian jual beli itu dilakukan dalam dua tahap yaitu tahap kesepakatan kedua belah pihak mengenai barang dan harga yang ditandai dengan kata sepakat (jual beli) dan yang kedua, tahap penyerahan (levering) benda yang menjadi obyek perjanjian, dengan tujuan untuk mengalihkan hak milik dari benda tersebut.

\section{Wajib Mutasi}

Kapan hak milik atas barang yang diperjual-belikan beralih kepada pembeli? Peralihannya terjadi setelah penyerahan barang oleh penjual. Penyerahan barang meliputi segala sesuatu yang menjadi perlengkapannya. Misalnya tanah dengan sertifikatnya, mobil/motor dengan BPKB-nya. KUHPerdata mengatur prosedur penyerahan barang sesuai dengan jenis dan sifat barang yang akan diserah-terimakan. Jika penjual lalai melakukan penyerahan barang maka pembeli dapat menuntut pembatalan pembelian.

Menurut Zaeni Asyhadie, penyerahan (levering) yaitu cara memperoleh hak milik yang didasarkan atas peralihan hak (perbuatan hukum) tertentu, sehingga 
pemilik semula dari suatu benda atau barang diharuskan untuk menyerahkan benda atau barang tersebut kepada pemilik yang baru.

Zaman sekarang, penyerahan (levering) merupakan hal yang terpenting. Perkataan "penyerahan" mempunyai dua arti:

"Pertama perbuatan yang berupa penyerahan kekuasaan belaka (feitelijke levering). Kedua perbuatan hukum yang bertujuan memindahkan hak milik kepada orang lain (juridische levering.

Dua pengertian tersebut terjadi dalam perjanjian jual beli kendaraan bermotor. Pertama serah terima kendaraan bermotor dari penjual kepada pembeli merupakan penyerahan nyata. Artinya, penjual telah menerima sejumlah uang dari pembeli, dan pembeli telah menerima barang (kendaraan bermotor) dari penjual. Kedua, pembeli melakukan pemindahan hak milik atas kendaraan bermotor dari nama penjual kepada nama pembeli. Peralihan hak milik yang harus didaftarkan pada instansi terkait sebagai dasar penetapan dalam Buku Pemilik Kendaraan Bermotor (BPKB).
Oleh karenanya, ada yang berpendapat bahwa: kendaraan bermotor termasuk benda bergerak atas nama atau barang terdaftar. Menurut J. Satrio:

"Dari namanya saja (BPKB), sudah ketahuan bahwa buku tersebut membuktikan pemilikan seseorang atas kendaraan tertentu.

Dengan kata lain, atas nama siapa Buku Pemilik Kendaraan Bermotor tersebut terdaftar merupakan pemilik sah kendaraan. Ini juga berarti BPKB merupakan bukti hak milik atas kendaraan bermotor yang otentik, dan mempunyai kepastian hukum.

Bagaimana pentingnya pengertian tentang "penyerahan" itu nampak jika dibandingkan dengan sistem KUH Perdata dengan system Code Civil mengenai masalah ini. Menurut Code Civil, dalam hal jual beli, hak milik berpindah pada saat jual beli ditutup. Sedangkan menurut sistem KUHPerdata suatu perjanjian jual beli belumlah berpindah hak milik, tanpa perbuatan "levering" yaitu untuk benda bergerak tidak terdaftar penyerahan dari tangan ke tangan, sementara untuk benda 
bergerak terdaftar (kendaraan bermotor) dan benda tidak bergerak melalui pengutipan "akte van transport" dalam buku atau daftar hak milik, yang disebut dengan "balik nama".

Menurut sistem KUHPerdata, pemindahan hak terdiri atas dua bagian. Pertama "obligatoire overeenkomst" yaitu setiap perjanjian yang bertujuan memindahkan hak, umpamanya perjanjian jual beli atau tukar menukar. Kedua "zakelijke overeenkomst" merupakan perjanjian yang bertujuan untuk mengalihkan benda itu. Dalam hubungan ini adalah penting apakah sah balik nama dalam hal jual beli benda bergerak terdaftar itu tergantung pada sah atau tidak sahnya perjanjian obligatoir? Atau dianggap terlepas dari obligatoire overeenkomst itu. Hal ini penting, bagi pihak ketiga, karena ada kemungkinan suatu perjanjian jual beli pada suatu ketika dibatalkan, karena ternyata orang yang telah menjual benda, yang sudah diserahkan tidak berhak menjual benda itu.

Pendapat yang lazim dianut oleh para pakar hukum dan para hakim, dalam KUHPerdata berlaku apa yang dinamakan "causal stelsel" yaitu sah atau tidaknya pemindahan hak milik itu tergantung pada sah atau tidaknya perjanjian obligatoir, misalnya perjanjian jual beli. Pada sistem ini, pemberian perlindungan terutama kepada pemilik, dengan mengorbankan pihak ketiga. Jika pertanyaan mengenai sah atau tidaknya levering itu dianggap terlepas dari sah atau tidaknya perjanjian obligatoir, hal seperti ini disebut "abstract stelsel", yaitu lebih mementingkan kepentingan perlindungan pihak ketiga. Dalam perspektif KUHPerdata, obligatoire overeenkomst itu tidak musti perjanjian secara tertulis, sehingga perjanjian jual beli diperbolehkan secara lisan, Namun, penyerahannya baik benda tidak bergerak maupun benda bergerak terdaftar harus dilakukan secara tertulis yang disebut "akte van transpor (disamakan dengan $\mathrm{BPKB}$ ) surat penyerahan, yang harus dibuat secara resmi (authentiek) oleh yang berwenang. Akte tersebut berupa suatu keterangan timbal balik dan ditanda tangani bersama oleh penjual dan pembeli. 
Akte, pada prinsipnya berisi di satu pihak penjual menyerahkan hak miliknya, dipihak lain pembeli menyatakan menerima hak milik dan benda yang bersangkutan. Selanjutnya pembeli menghadap pegawai pengurusan balik nama (overschrijvingsambtenaar), sekarang di Sistem Administrasi Manunggal Satu Atap.

Berkenaan dengan Pasal 1459 KUHPerdata, Pemerintah telah mengeluarkan Undang-Undang Nomor 28 Tahun 2009 tentang Pajak Daerah dan Retribusi Daerah serta Pemerintah Aceh sudah menetapkan Qanun Aceh Nomor: 2 Tahun 2012 tentang Pajak Aceh dan Peraturan Gubernur Aceh Nomor 11 Tahun 2012 tentang Pelaksanaan Qanun Aceh Nomor 2 Tahun 2012 tentang Pajak Aceh. Ketentuan dalam Qanun Aceh Nomor: 2 Tahun 2012 sebagai berikut:

Pasal 10: “...Bea Balik Nama Kendaraan Bermotor dipungut pajak "penyerahan" kepemilikan kendaraan bermotor".

Pasal 11 ayat (1): “Obyek Bea Balik Nama Kendaraan Bermotor adalah penyerahan kepemilikan kendaraan bermotor".
Pasal 13 ayat (3) Yang bertanggung jawab atas pembayaran bea interpretasi data interpretasi data interpretasi data balik nama kendaraan bermotor adalah:

a. Untuk orang pribadi adalah orang yang bersangkutan, kuasanya atau ahli warisnya; dan

b. Untuk badan adalah pengurus atau kuasanya. Pasal 14 ayat (4) Pemilik kendaraan bermotor yang menggunakan nomor polisi non BL yang beroperasi di wilayah Aceh, wajib melaporkan kendaraannya kepada Pemerintah Aceh melalui Kantor Samsat terdekat dalam waktu 90 (sembilan puluh) hari; ayat (5) Pemilik kendaraan bermotor sebagaimana dimaksud pada ayat (4) yang telah mengoperasionalkan kendaraan di wilayah Aceh selama 12 (dua belas) bulan, wajib memutasikan kendaraannya.

Pasal 71 ayat (1) huruf $\mathrm{c}$ dan $\mathrm{d}$ Undang-Undang Nomor 22 Tahun 2009 tentang Lalu Lintas dan Angkutan Jalan (UULAJ) menjelaskan bahwa: pemilik kendaraan bermotor wajib melaporkan kepada Kepolisian Negara Republik Indonesia jika kepemilikan kendaraan bermotor beralih; atau kendaraan bermotor 
digunakan secara terus menerus lebih dari 3 (tiga) bulan di luar wilayah kendaraan diregistrasi. Ayat (2) Pelaporan kendaraan bermotor sebagaimana dimaksud pada ayat (1) huruf d disampaikan kepada Kepolisian Negara Republik Indonesia di tempat kendaraan bermotor tersebut beroperasi. Surat Tanda Nomor Kendaraan (STNK) tidak sah lagi sesudah 2 (dua) bulan terhitung dari saat yang diberikan STNK itu atas namanya, tidak lagi menjadi pemilik kendaraan bermotor tersebut.

Jelaslah peraturan-peraturan yang mengatur tentang Bea Balik Nama Kendaraan Bermotor dan wajib mutasi kendaraannya yang telah disebutkan di atas, ada tenggang waktunya diberikan kepada pembeli, walaupun dalam waktu yang berbeda. Untuk mengadakan balik nama kendaraan bermotor dari pemilik yang lama kepada pemilik yang baru dan mutasi kendaraannya dari non BL ke BL Menurut asas Nullus/nemo commondum capere potest de injuria sua propia". Tidak seorang pun boleh diuntungkan oleh penyimpangan dan pelanggaran yang dilakukannya sendiri dan tidak seorang pun boleh dirugikan oleh penyimpangan dan pelanggaran yang dilakukan oleh orang lain. Namun, dalam kenyataannya semua harapan itu tidak selamanya dapat terwujud.

Sebagaimana diketahui sejak lima tahun terakhir, PAD Aceh hanya tumbuh sebesar 10,9 persen, jauh dibawah rata-rata nasional yang mencapai 19 persen. Bandingkan dengan Provinsi Kalimantan Timur yang PAD-nya tumbuh sebesar 30,7 persen pertahun dan Provinsi Lampung sebesar 29,5 persen. Sementara itu Kepala Dinas Pendapatan Daerah, Muhammad mengakui pertumbuhan PAD yang cenderung stagnan. Menurutnya, masih ada kendala dalam meningkatkan PAD Aceh.

Berdasarkan Pasal 71 ayat (1) huruf c dan d Undang-Undang Nomor 22 Tahun 2009 tentang Lalu Lintas dan Angkutan Jalan (UULAJ) tersebut di atas, jelaslah bahwa setiap pemilik/pemegang kendaraan bermotor diwajibkan melaporkan kendaraannya pada saat terjadinya pemindahan hak dan/atau pada saat berlakunya STNK berakhir. Selain 
itu, telah ditetapkan tata caranya/ pemberitahuan dilakukan untuk setiap kendaraan bermotor satu persatu dengan memasukkan surat permohonan menurut contoh yang ditetapkan untuk itu yang di isi lengkap dan ditanda tangani oleh pemilik/pemegang atau kuasanya.

Berdasarkan penjelasan yang telah diuraikan di atas, dapat dipahami bahwa ternyata meskipun pembuat undang-undang waktu itu (saat Kekaisaran Romawi mulai melakukan Kodifikasi Hukum) melakukan pembagian yang demikian berkotak-kotak atas bermacammacam hukum (hukum privat dan hukum publik) yang berlaku dalam masyarakat, pada kenyataannya dapat dilihat bahwa sejalan dengan perkembangan hukum, baik itu lewat penambahan peraturan perundangundangan maupun lewat yurisprudensi pengkotak-kotakan tersebut mulai tersamar.

Sejalan dengan pendapat tersebut, Kelsen mengemukakan:

"In all modern legal orders, the state, as well as any other juristic person, may have rights in personam, may any of the rights and duties stipulated by private law. When there is civil code, it is norm apply to private persons an the state".

Sistem hukum modern, sebagaimana halnya dengan hak perseorangan lainnya, Negara dapat mempunyai hak in rem dan hak in personam, atas segala hak dan kewajiban yang diatur oleh hukum perdata. Jika ada ketentuan-ketentuan hukum perdata, maka normanormanya diperlakukan sama, baik untuk kepentingan perorangan maupun untuk kepentingan Negara.

Pada era globalisasi sekarang hampir tidak mungkin lagi dalam fungsinya membedakan antara hukum privat dengan hukum publik. Walaupun dalam pembagiannya tetap dipertahankan adanya hukum privat dan hukum publik. Akan tetapi dalam implementasinya perlu kerjasama antara kedua hukum tersebut dalam rangka mengisi kevacuman hukum dan untuk mencapai tujuan hukum yakni keadilan.

Menurut Pasal 71 ayat (1) huruf c dan d Undang-Undang Nomor 22 Tahun 2009 tentang Lalu Lintas dan Angkutan Jalan (UULAJ) dan Pasal 10 Qanun Aceh Nomor 2 Tahun 2012 tentang Pajak Aceh, dapatlah 
dipahami bahwa perjanjian jual beli kendaraan bermotor termasuk dalam katagori formal contrac. Perjanjian yang terikat pada bentuk tertentu, jadi bentuknya harus sesuai dengan ketentuan-ketentuan yang berlaku. Jika bentuk perjanjian tidak sesuai dengan ketentuan, maka perjanjian tersebut tidak sah. Maksudnya adalah perjanjian jual beli kendaraan bermotor sudah ada cara-cara tertentu yang harus dipenuhi sesuai ketentuan, sehingga dapat memberikan kepastian hukum bagi para pihak. Berdasarkan penjelasan tersebut, pembeli setelah menerima serah terima kendaraan bermotor dari pejual berkewajiban melakukan balik nama dari nama penjual ke nama pembeli. Sehingga kendaraan bermotor tersebut, baik secara hukum materil dan hukum formil telah menjadi sah milik pembeli.

Selain itu, juga telah mendapatkan kepastian hukum kepemilikan atas kendaraan bermotor. Lagi pula dengan membayar bea balik nama kendaraan bermotor sudah membantu pemerintah daerah dalam upaya peningkatan Pendapatan Asli Aceh (PAA). Sehingga saling menguntungkan baik penjual, pembeli maupun pemerintah daerah sebagai penyedia sarana dan prasarana untuk kemakmuran rakyat.

Berdasarkan hasil pengamatan di lapangan ternyata penjual maupun pembeli kendaraan bermotor bekas pakai melakukan transaksi jual beli belum sesuai dengan aturan yang tersebut di atas. Peristiwa ini umumnya terjadi bukan karena penjual atau pembeli tidak memiliki pengetahuan yang cukup mengenai hal ini. Dalam pelaksanaan perjanjian jual beli kendaraan bermotor bekas pakai antara penjual dan pembeli, oleh kedua pihak dianggap perbuatan tersebut sudah selesai. Penjual telah menerima sejumlah harga sementara pembeli telah menerima kendaraan bermotor.

Padahal pertanggungjawaban mereka belum berakhir, seyogianya penjual menuliskan harga kendaraan bermotor dalam kwitansi sesuai dengan jumlah yang dibayar oleh pembeli. Dalam kenyataan tidak demikian, nilai dalam kwintasi lebih kecil dari pada uang yang disetor pembeli. Manfaatnya untuk menurunkan nilai pajak kendaraan 
bermotor dan bea balik nama kendaraan bermotor pada saat disetor ke SAMSAT. Sementara pembeli seharusnya setelah serah terima kendaraan bermotor wajib melakukan balik nama dari nama penjual kepada nama pembeli. Sehingga menjadi pemilik sah atas kendaraan tersebut. Ironisnya, secara implisit penjual ikut berpartisipasi agar pembeli tidak melakukan balik nama kendaraan bermotor, dengan cara bersedia memberikan fotocopy KTP untuk memperpanjang STNK. Hal ini akan berpengaruh pada kepastian hukum dalam hal kepemilikan kendaraan bermotor dan dalam upaya peningkatan Pendapatan Asli Aceh (PAA), akibat perbuatan mereka yang tidak bertanggungjawab.

\section{C.SIMPULAN}

Perjanjian jual beli kendaraan bermotor termasuk dalam katagori formal contrac. Perjanjian yang terikat pada bentuk tertentu, jadi bentuknya harus sesuai dengan ketentuan-ketentuan yang berlaku. Jika bentuk perjanjian tidak sesuai dengan ketentuan, maka perjanjian tersebut tidak sah. Maksudnya adalah perjanjian jual beli kendaraan bermotor sudah ada cara-cara tertentu yang harus dipenuhi sesuai ketentuan, sehingga dapat memberikan kepastian hukum bagi para pihak.

Berdasarkan penjelasan tersebut, pembeli setelah menerima serah terima kendaraan bermotor dari pejual berkewajiban melakukan balik nama dari nama penjual ke nama pembeli. Sehingga kendaraan bermotor tersebut .baik secara hukum materil dan hukum formil telah menjadi sah milik pembeli. Selain itu, akan menambah pendapatan asli daerah yang bersumber dari bea balik nama kendaraan bermotor.

\section{DAFTAR PUSTAKA}

Kartini, Mulyadi, dan Gunawan, Widjaja, Seri Hukum Harta Kekayaan, Kebendaan pada Umumnya, Kencana, Jakarta, 2003.

Niniek, Suparni, Kitab UndangUndang Hukum Perdata (KUHPerdata), Cet-8, Rineka Cipta, Jakarta, 2013.

Rahmadi, Usman, Hukum Kebendaan, Sinar Grafika, Jakarta, 2011. 
Ratna, Artha, Windari, Hukum Perjanjian, Graha Ilmu, Yogyakarta, 2014.

Satrio, J., Perjanjian Sewa Beli Kendaraan Bermotor, Proyek Pengembangan Tehnis Yustisial MA RI, Jakarta, 1989.

Subekti, R., Pokok-pokok Hukum Perdata, Cet Ke-XXXI, Intermasa, Jakarta, 2003.

Syahmin A.K., Hukum Kontrak Internasional, Rajawali Pers, Jakarta, 2011.

Waskita, dkk. Kamus Ekslusif, Kamus terlengkap dan Terkini, InggrisIndonesia, Indonesia-Inggris, PT. Masmedia Buana Pustaka, Surabaya.

Yahya, Harahap, M., Segi-segi Hukum Perjanjian. Cetakan Kedua, Alumni, Bandung, 1989.

Zaeni, Asyhadie., Hukum Bisnis Prinsip dan Pelaksanaannya di Indonesia, Rajawali Pres, Jakarta, 2009.

Undang-Undang Nomor 22 Tahun 2009 tentang Lalu Lintas dan Angkutan Jalan (UULAJ).

Undang-Undang Nomor 28 Tahun 2009 tentang Pajak Daerah dan Retribusi Daerah.
Undang-Undang Nomor 12 Tahun 2011 tentang Pembentukan Peraturan Perundang-undangan.

Peraturan Gubernur Aceh Nomor 11 Tahun 2012 tentang Pelaksanaan Qanun Aceh Nomor 2 Tahun 2012 tentang Pajak Aceh.

Qanun Aceh Nomor 2 Tahun 2012 tentang Pajak Aceh.

IdrisSubrata,SegalaSesuatuTentangH ukum,http://muhammadsubrata.blogs pot.com/2013/12/perjanjian-jualbeli.html.

Law Office Muhadjirin, Kristof \& Partner, Jual Beli Menurut Perspektif Hukum

Perdata,http://klinikhukumku.blogspo t.com/2012/07/jual-beli-menurutperspektif-hukum.html.

http://www.tempo.co/read/news/2013/ 10/25/058524494/Pendapatan-AsliDaerah-Aceh-Cenderung-Stagnan.

http://hukum.kompasiana.com/2010/0 8/25/asas-kebebasan-berkontrakdalam-hukum-perjanjian-diindonesia-238895.html. 